\title{
Positive Word of Mouth (WoM) Sebagai Komunikasi Pemasaran Universitas Abdurrab Pekanbaru Saat Pandemi Covid-19
}

\author{
Suci Shinta Lestari ${ }^{1}$, Muhammad Arif ${ }^{2}$ \\ ${ }^{1,2}$ Universitas Abdurrab Pekanbaru \\ Email: suci.shinta@univrab.ac.id
}

\begin{abstract}
Many companies, institutions, organizations and even personalities rely on positive WoM as an important marketing communication tool, including private universities such as Universitas Abdurrab Pekanbaru. Encouraging an increase number of new students through student recommendations to prospective new students or word of mouth (WOM) is a positive marketing tool that bring benefits to the institution. This research aims to describe some of the methods used by Universitas Abdurrab for creating or stimulating word of mouth as a marketing communication tool during the Covid-19 pandemic. This research is literary research, which is a series of studies relates to the method of collecting library data or research in which the object of research is explored through a variety of library information (books, scientific journal and documents). The results of the research showed that there are several methods used by Universitas Abdurrab to create or stimulate word of mouth as a marketing communication tool during the Covid-19 pandemic, namely buzz marketing, cause marketing, viral marketing, and Influencer marketing.
\end{abstract}

Keywords: Positive word of mouth, marketing communication, Covid-19 pandemic

\begin{abstract}
Abstrak: Banyak perusahaan, institusi, organisasi bahkan personal mengandalkan positive WoM sebagai alat komunikasi pemasaran, tidak terkecuali PTS seperti Universitas Abdurrab Pekanbaru. Mendorong peningkatan jumlah mahasiswa baru melalui rekomendasi mahasiswa kepada calon mahasiswa baru atau Word of Mouth (WoM) merupakan alat pemasaran positif yang dapat mendatangkan manfaat bagi institusi. Penelitian ini bertujuan untuk memaparkan beberapa metode yang dipakai Universitas Abdurrab untuk menciptakan atau merangsang terjadinya Word of Mouth sebagai alat komunikasi pemasaran saat pandemi Covid-19. Penelitian ini adalah penelitian kepustakaan (literacy research), yaitu serangkaian penelitian yang berkenaan dengan metode pengumpulan data pustaka atau objek penelitiannya digali melalui beragam informasi kepustakaan (buku, jurnal ilmiah dan dokumen). Hasil penelitian menunjukkan bahwa terdapat beberapa metode yang dipakai Universitas Abdurrab untuk menciptakan atau merangsang terjadinya word of mouth sebagai alat komunikasi pemasaran saat pandemi Covid-19 yakni buzz marketing, cause marketing, viral marketing dan influencer marketing.
\end{abstract}

Kata kunci: Perkataan positif dari mulut ke mulut, komunikasi pemasaran, pandemi Covid-19 


\section{KOMUNIKASIANA \\ Journal of Communication Studies}

\section{Pendahuluan}

Saat ini, jumlah perguruan tinggi swasta (PTS) di Indonesia sudah sekitar 2.136. Setyawan (2015) menyatakan bahwa PTS yang menyadari bahwa kompetisi antar perguruan tinggi perlu dikelola secara baik dan profesional seperti perusahaan yang berorientasi profit biasanya tidak mengalami kesulitan dalam hal pemasaran. Hal ini karena kegiatan pemasarannya dilakukan oleh unit tersendiri. Namun bagi PTS yang belum menyadari bahwa persaingan merekrut calon mahasiswa baru semakin sulit, maka mereka cenderung hanya melakukan kegiatan pemasaran dengan dukungan sumber daya yang sangat terbatas.

Menyusun strategi pemasaran bagi PTS bertujuan untuk membantu membentuk pola pikir yang sistematis sehingga dapat digunakan sebagai pedoman koordinasi bagi unit yang terlibat dalam kegiatan pemasaran. Strategi pemasaran PTS merupakan serangkaian kebijakan dan aturan yang memberi arah dalam mengelola pemasaran secara terpadu dan menyatu dengan mempertimbangkan kondisi internal dan eksternal. Untuk itu, strategi pemasaran merupakan bagian terintegrasi dari strategi PTS yang dapat digunakan sebagai arah pada semua lapisan manajemen.

Alma dalam Sopandi (2011) menyatakan bahwa secara dikotomik ada dua klasifikasi posisi PTS, yaitu PTS kuat dan PTS lemah, PTS kuat berada pada posisi sellers market, yang sangat menguntungkan karena mendapat banyak peminat sebagai refleksi citra baik dari masyarakat dan adanya product differentiation yang memiliki keunggulan monopolistic elements. Sedangkan PTS lemah berada pada posisi buyers market yaitu posisi yang penuh persaingan dengan PTS lainnya. PTS kuat dan lemah tersebut telah berusaha sesuai kemampuannya mendesain strategi untuk meraih mahasiswa baru dalam berbagai bentuk, seperti mengembangkan strategi bauran pemasaran yang meliputi product, price, place, promotion, dan personal traits; membina dan mengembangkan organisasi alumnni yang dapat membantu lembaga dalam bentuk moril seperti meningkatkan nama baik lembaga, maupun dalam bentuk materil dan memelihara hubungan PTS dengan variabel eksternal seperti KOPERTIS (saat ini disebut LLDIKTI), perguruan tinggi negeri dan publik lainnya yang dapat membuka berbagai peluang dan sekaligus merupakan tantangan.

Penyebaran Covid-19 sejak akhir 2019 mengubah berbagai strategi komunikasi pemasaran untuk menarik minat pelanggan. Pada masa ini perusahaan diharuskan dapat memaksimalkan berbagai potensi dan peluang untuk tetap dapat bertahan. Melaksanakan strategi pemasaran dengan anggaran kecil bahkan nol rupiah sangat dibutuhkan dimasa Covid19. Perusahaan dan organisasi perlu bersikap bijak dan strategis terhadap pengeluaran yang dibelanjakan untuk usaha pemasaran karena situasi yang serba sulit. Strategi pemasaran murah dan terjangkau adalah dengan memanfaatkan saluran komunikasi. Komunikasi adalah "darah kehidupan" (lifeblood) setiap organisasi sebab komunikasi sangat penting, sehingga tanpa komunikasi maka organisasi tidak dapat berfungsi. Baik organisasi bisnis atau bukan, maka komunikasi yang efektif dan tepat baik lisan atau tulisan ibarat darah yang mengalir pada tubuh manusia.

Sutisna dalam Fadillah (2015) menyatakan bahwa kebanyakan komunikasi antar manusia adalah melalui dari mulut ke mulut. Setiap orang setiap hari berbicara dengan yang lainnya, saling tukar pikiran, saling tukar informasi, saling berkomentar dan sederetan proses komunikasi lainnya. 
Dari berbagai penelitian, diketahui bahwa sebenarnya pengetahuan konsumen atas berbagai macam merek produk disebabkan karena adanya komunikasi dari mulut ke mulut. Hal tersebut sangat menguntungkan produsen yang jarang melakukan promosi dan lemah dalam mengomunikasikan produknya melalui media massa dikarenakan keterbatasan biaya, sehingga sulit menjangkau konsumen yang lebih luas.

Pada lingkup komunikasi pemasaran, informasi yang secara simultan yang disampaikan oleh pelanggan satu ke calon pelanggan lain akan menciptakan positioning tertentu pada sebuah perusahaan, organisasi dan personal. Positioning tersebut ada yang positif dan ada yang negatif. Dari fenomena ini, bisa dilihat bagaimana positioning perusahaan, organisasi bahkan personal dapat terbentuk dari word of mouth (WOM). Pada konteks produk komersial, fenomena kesuksesan film TILIK dapat dijadikan contoh. Berdasarkan pengamatan, film ini justru terpasarkan karena komunikasi di antara masyarakat yang penasaran dengan fenomena Bu Tejo yang diperankan oleh salah satu pemain.

Sebuah penelitian yang dilakukan oleh Onbee Marketing Research-Octovate Consulting Group dan majalah SWA yang memperlihatkan bahwa konsumen di Indonesia umumnya menyampaikan hal-hal positif (positive word of mouth) kepada 7 orang lain jika ia merasa puas. Sedangkan konsumen yang tidak puas cenderung akan menyampaikan hal-hal negatif tentang produk tersebut (negative word of mouth) kepada 11 orang. Hal ini menandakan bahwa konsumen akan cenderung menyebarkan negative word of mouth yang lebih banyak dari pada positive word of mouth.

Quicksprout pernah membuat riset mengenai cara-cara memasarkan produk dengan baik. Dari riset diketahui bahwa dua dari tiga poin teratas yakni rekomendasi dari teman dan opini netizen di sosial media, menjadi daya tarik seseorang untuk membeli. Dari riset tersebut, bisa terlihat jika pelanggan secara alami akan datang membeli melalui rekomendasi-rekomendasi bukan melalui iklan berbayar seperti yang ada di internet.

Word of mouth dalam ilmu pemasaran atau marketing adalah sebuah komunikasi tentang produk dan jasa antara orang-orang yang dianggap independen dari perusahaan yang menyediakan produk atau jasa, dalam medium yang akan dianggap independen dari perusahaan. Komunikasi WOM bisa berupa percakapan atau testimonial seperti berbicara langsung, melalui telepon, email, list group atau sarana komunikasi lainnya. Di era 4.0 saat ini masyarakat dibanjiri dengan ribuan pesan iklan, promosi serta pesan pribadi, sehingga arus WOM dari orang-orang yang mereka percaya amatlah penting. Promosi yang keluar dari mulut mahasiswa yang puas berkuliah di satu PTS dapat secara signifikan mendongkrak reputasi PTS tersebut. Hal itu juga berpengaruh pada bagaimana persepsi calon mahasiswa dapat dibentuk, dan tren baru yang dapat terbentuk.

Dengan perkembangan teknologi, WOM sebenarnya sudah tidak lagi dilakukan secara tradisional yakni secara lisan atau face to face, namun sudah dilakukan melalui jaringan internet, sehingga jangkauannya menjadi lebih luas dan tidak hanya melibatkan orang terdekat melainkan juga orang yang diidolakan yang meskipun tidak memiliki ikatan, namun setiap tindakannya memberikan pengaruh pada orang yang mengidolakannya. Dengan demikian menarik untuk mengetahui lebih banyak tentang WOM yang digunakan sebagai salah satu strategi pemasaran PTS khususnya saat penerimaan mahasiswa baru diera pandemi Covid-19 seperti saat sekarang ini, di mana strategi pemasaran telah banyak beradaptasi dengan kondisi 
new normal. Penelitian ini bertujuan untuk memaparkan beberapa metode yang dipakai Universitas Abdurrab Pekanbaru untuk menciptakan atau merangsang terjadinya positive word of mouth sebagai alat komunikasi pemasaran saat pandemi Covid-19.

\section{Metode}

Penelitan ini adalah penelitian kepustakaan (literacy research), yaitu serangkaian penelitian yang berkenaan dengan metode pengumpulan data pustaka atau penelitian yang objek penelitiannya digali melalui beragam informasi kepustakaan (buku, jurnal ilmiah dan dokumen). Penelitian kepustakaan atau kajian literatur (literature review, literature research) merupakan penelitian yang mengkaji atau meninjau secara kritis pengetahuan, gagasan atau temuan yang terdapat di dalam tubuh literatur berorientasi akademik (academic-oriented literature), serta merumuskan kontribusi teoritis dan metodologisnya untuk topik tertentu. Fokus penelitian kepustakaan adalah menemukan berbagai teori, hukum, dalil, prinsip atau gagasan yang digunakan untuk menganalisis dan memecahkan pertanyaan penelitian yang dirumuskan.

Adapun jenis penelitian ini adalah deskriptif, yakni penguraian secara teratur data yang telah diperoleh, kemudian diberikan pemahaman dan penjelasan agar dapat dipahami dengan baik. Data yang digunakan dalam penelitian ini adalah data primer dan sekunder. Data Primer merupakan data yang diperoleh dari pengamatan langsung, sedangkan data sekunder merupakan data yang diperoleh dari hasil penelitian yang telah dilakukan oleh peneliti-peneliti terdahulu. Sumber data sekunder yang dimaksud berupa buku dan laporan ilmiah primer atau asli yang terdapat di dalam artikel atau jurnal (tercetak atau non cetak) berkenaan dengan word of mouth (WOM).

\section{Hasil dan Pembahasan}

Word of Mouth diartikan sebagai pertukaran ide, pikiran dan komentar antar dua atau lebih konsumen dan tidak satupun dari mereka adalah pemasar (Putri, 2018). Christopher H. Lovelock dan Lauren K. Wright dalam Suryani et al (2017) menyatakan bahwa Word of Mouth adalah salah satu bentuk komunikasi pemasaran walaupun sulit bagi pemasar mengontrol saluran ini. Tidak ada sebuah iklan atau seorang penjualpun yang akan mampu meyakinkan anda secara persuasif tentang kualitas suatu produk selain seorang teman, kenalan, pelanggan lama atau ahli independent.

Saat penerimaan mahasiswa baru, PTN masih menjadi tujuan favorit para pelajar SMU di mana pada tahun 2015 saja, total kapasitas PTN di Indonesia mencapai 270.000 kursi, sementara jumlah pendaftar mencapai 852.093 siswa. Tingginya minat siswa untuk masuk PTN ini terus terjadi hingga 2020 meski PTS juga sudah semakin banyak yang mempunyai kualitas sama. Hal ini menjadi tantangan bagi PTS terutama di Kota Pekanbaru untuk bersaing memperebutkan calon mahasiswa baru.

Banyak instansi yang mengandalkan positive WOM sebagai komunikasi pemasaran begitu juga dengan Universitas Abdurrab Pekanbaru. Hal ini karena positive WOM ditemukan sembilan kali lebih efektif digunakan segai alat promosi periklanan perusahaan dibandingkan dengan periklanan tradisional (Riorini \& Widayati, (2018). Untuk menciptakan positive WOM, tergantung dari terciptanya kepuasan konsumen atau customer satisfaction dan kualitas 
pelayanan atau service quality yang diberikan. Untuk meningkatkan service quality, banyak PTS menjawabnya melalui peningkatan fasilitas kampus dengan menggunakan pelayanan online atau e-service quality. Kondisi terkini di Indonesia terkait perpanjangan masa status darurat Covid-19 berdampak signifikan pada seluruh aspek kehidupan kita, termasuk pada sektor pendidikan. Situasi ini tentu akan berdampak besar bagi berbagai aktivitas kampus, salah satunya proses penerimaan mahasiswa baru (PMB) sebagai agenda rutin kampus mendapatkan mahasiswa baru. Pembatasan aktivitas keluar rumah dan himbauan "\#dirumahaja” dalam rangka upaya pembatasan penyebaran virus Corona tentu akan sangat menghambat metode promosi dan pendaftaran konvensional, jika pihak manajemen kampus tidak tanggap dan tidak segera mengambil keputusan tepat dalam situasi saat ini, bisa diprediksi akan terjadi penurunan yang signifikan jumlah mahasiswa baru yang masuk perguruan tinggi tersebut pada tahun ajaran baru mendatang. Oleh sebab itu selama pandemi Covid-19 Universitas Abdurrab Pekanbaru membuka pendaftaran secara online untuk memudahkan calon mahasiswa mendaftar dengan tetap berada di daerah domisili.

Gambar 1. Tampilan Website Penerimaan Mahasiswa Baru Universitas Abdurrab

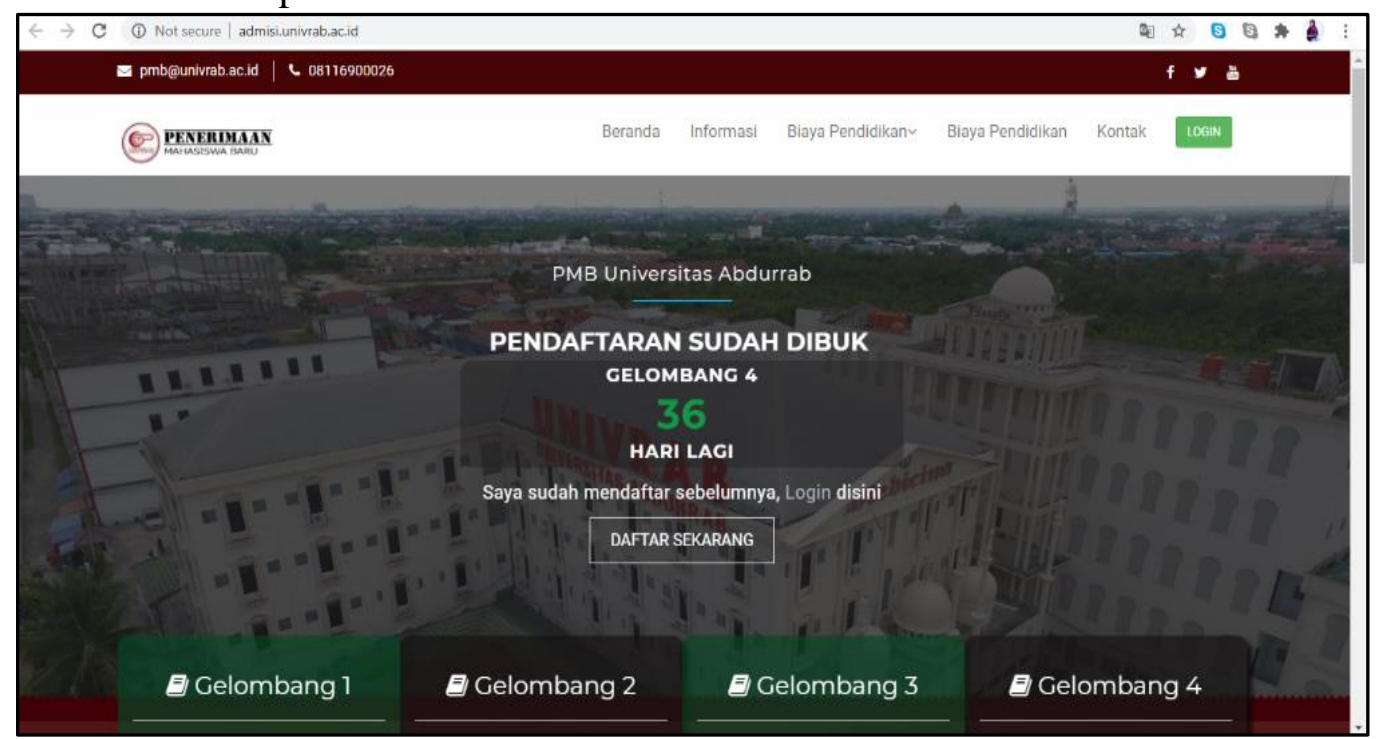

Sumber : Dokumentasi Universitas Abdurrab

Dari Gambar 1 di atas cara pendaftaran yang semula melalui pengisian formulir kertas kemudian diserahkan kepada panitia PMB kemudian dilaksanakan secara online dengan memanfaatkan website dan google form. Hal ini karena metode pendaftaran konvensional sudah tidak memadai untuk memberikan layanan cepat agar calon mahasiswa tidak terlanjur pindah kelain hati sebelum panitia PMB sempat memfollow-up mereka melalui balasan email ataupun telepon calon mahasiswa satu per satu. Universitas Abdurrab menyediakan cara pendaftaran yang simpel dan cepat. Calon mahasiswa baru tidak dibuat pusing dengan mengisi data untuk keperluan proses pendaftaran yang langsung terkoneksi secara otomatis dengan pembayaran uang pendaftaran. Berikut ini adalah alur kerja dari program aplikasi PMB online Universias Abdurrab pada gambar 1 di atas : 
Tabel 1. Alur Kerja Program Aplikasi PMB Online Universias Abdurrab

\begin{tabular}{|c|c|}
\hline No & Tahapan dalam PMB \\
\hline 1 & Dari website, calon mahasiswa dapat melihat pengumuman yang ada. \\
\hline 2 & Calon mahasiswa membuat akun dan login dari website PMB Online. \\
\hline 3 & $\begin{array}{l}\text { Calon mahasiswa dapat mendaftarkan diri secara online dari website utama sistem } \\
\text { PMB online, yaitu dengan cara mengisi formulir pendaftaran dengan mengisi data } \\
\text { lengkap. Selanjutnya data yang sudah diinput dapat diperbaiki jika ada yang salah. }\end{array}$ \\
\hline 4 & $\begin{array}{l}\text { Calon mahasiswa dapat melengkapi form pendaftarannya dengan mengirim berkas } \\
\text { syarat-syaratnya lewat upload berkas, dengan memaket datanya dalam bentuk PDF } \\
\text { atau file gambar. }\end{array}$ \\
\hline 5 & $\begin{array}{l}\text { Calon mahasiswa dapat mentransfer biaya pendaftaran sebagai syarat mendaftar } \\
\text { sebesar (misalnya empat ratus ribu rupiah) ke rekening kampus, kemudian bukti } \\
\text { transfer dapat discan dan dikirim melalui form pengiriman bukti syarat dalam } \\
\text { website PMB online. }\end{array}$ \\
\hline 6 & $\begin{array}{l}\text { Calon mahasiswa yang datanya sudah divalidasi oleh panitia PMB, akan mendapat } \\
\text { undangan untuk mengikuti tes langsung secara online. }\end{array}$ \\
\hline 7 & $\begin{array}{l}\text { Calon mahasiswa dapat melihat hasil seleksi yang dilakukan oleh panitia PMB. } \\
\text { Hasilnya, yaitu apakah DITERIMA atau DITOLAK. Informasi ini secara otomatis } \\
\text { akan muncul di halaman web sistem PMB online. }\end{array}$ \\
\hline 8 & $\begin{array}{l}\text { Calon mahasiswa yang dinyatakan DITERIMA, diwajibkan untuk melakukan } \\
\text { registrasi ulang (pendaftaran ulang) ke kampus, dengan membayar biaya daftar } \\
\text { ulang. }\end{array}$ \\
\hline 9 & Pendaftaran ulang dilakukan oleh panitia PMB. \\
\hline 10 & $\begin{array}{l}\text { Calon mahasiswa yang sudah daftar ulang dicatat menjadi mahasiswa baru pada } \\
\text { Universitas Abdurrab }\end{array}$ \\
\hline 11 & $\begin{array}{l}\text { Panitia PMB kemudian membagi mahasiswa baru tersebut ke dalam kelas masing- } \\
\text { masing, misalnya kelas } 1 \mathrm{~A} \text {, kelas } 1 \mathrm{~B} \text { dan seterusnya. }\end{array}$ \\
\hline
\end{tabular}

Gambar 2. Informasi Pendaftaran Online Universitas Abdurrab

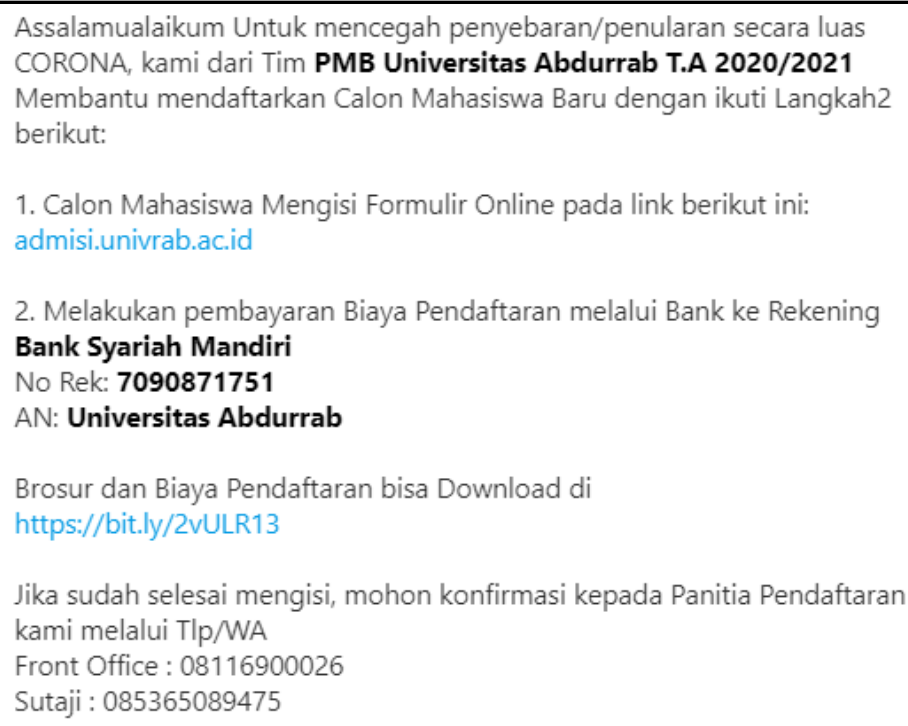

Sumber : Dokumentasi Universitas Abdurrab 
Word of mouth berawal dari sebuah bentuk yang timbul secara alamiah dan tidak didesain oleh perusahan juga pemasar. Word of mouth timbul karena keunggulan produk dan kualitas pelayanan. Selama pandemi Covid-19 oleh Universitas Abdurrab, word of mouth ditujukan untuk menggantikan program komunikasi pemasaran konvensional seperti turun ke daerahdaerah yang semakin kehilangan kredibilitasnya dan sekaligus karena peraturan pemerintah terkait Pembatasan Sosial Berskala Besar (PSBB). Ini juga mengurangi biaya produksi brosur dan aktivitas bagi-bagi brosur sehingga biaya operasional dapat lebih ditekan.

Secara umum word of mouth adalah oral person to person communication, komunikasi lisan antara individu dan individu lainnya, antara pengirim dan penerima pesan yang di dalamnya memiliki unsur produk, jasa maupun brand. Word of mouth adalah pembicaraan yang secara alami terjadi di antara orang-orang. Word of mouth adalah pembicaraan konsumen asli (Sernovitz, 2006).

Sebagai bagian dari bauran komunikasi pemasaran, Word of mouth communication menjadi salah satu strategi yang sangat berpengaruh di dalam keputusan konsumen untuk menggunakan produk atau jasa. Traditional word of mouth telah terbukti memunyai peran besar pada keputusan pembelian konsumen dengan memengaruhi pilihan konsumen. Word of mouth sering kali dikatakan dengan istilah viral marketing, yaitu sebuah teknik pemasaran yang digunakan untuk menyebarkan sebuah pesan pemasaran dari satu website atau penggunapengguna kepada website atau para pengguna lain, yang dapat menciptakan pertumbuhan eksponensial yang potensial seperti layaknya sebuah virus. Menurut Sernovitz (2006) word of mouth begitu efektif karena asal kepercayaanya adalah datang dari orang yang tidak mendapatkan keuntungan dari rekomendasi mereka.

Beberapa metode yang dipakai Universitas Abdurrab untuk menciptakan atau merangsang terjadinya word of mouth, yang merupakan salah satu strategi pemasarannya saat pandemic Covid-19, yakni, Pertama buzz marketing, menggunakan kegiatan hiburan atau berita yang bagus didukung oleh local buzzer supaya orang membicarakannya. Buzz marketing adalah strategi marketing untuk meningkatkan engagement melalui mulut ke mulut. Adapun mulut yang dimaksud dalam hal ini adalah mulut dari para buzzer. Secara umum, buzz marketing merupakan bagian dari viral marketing. Jadi, secara sederhana, strategi marketing ini memanfaatkan buzzer untuk terus membicarakan produk atau layanan agar menjadi trending di dunia maya. Secara tidak langsung, lama-kelamaan orang-orang juga akan tertarik membicarakan produk tersebut dan menceritakannya kepada orang terdekatnya. Dengan demikian, engagement bisnis akan meningkat.

Universitas Abdurrab mendesain dan melaksanakan kegiatan hiburan santai yang tetap dikemas informatif dalam bentuk live talkshow di media sosial Instagram. Setiap prodi diberikan tanggung jawab untuk mengisi kegiatan dibantu oleh tim pusat komputer dan humas. Kegiatan buzzer yang dipilih adalah yang tidak berbayar. Karena buzzer tidak tersistem dan murni dapat menggiring opini karena kecintaannya terhadap sesuatu maka dapat diupayakan lewat menjalin hubungan yang baik yang saling menguntungkan antar kedua belah pihak meski bukan secara finansial. Dalam kegiatan ini baik buzzer ataupun universitas sama-sama mendapatkan eksposur dari kegiatan yang dilakukan. Seperti contoh di bawah ini : 
Gambar 3. Kegiatan Hiburan yang Informatif Saat Pandemi Covid-19

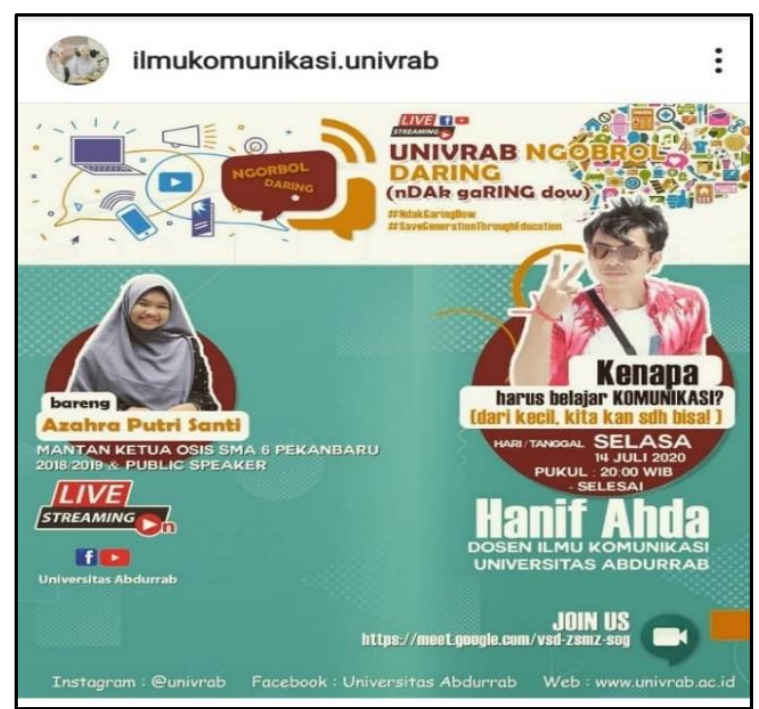

Sumber : Dokumentasi Universitas Abdurrab

Kedua, cause marketing, memberikan dukungan untuk program sosial melalui pengumpulan dana untuk mendapatkan respek dan dukungan dari orang-orang yang memiliki concern yang sama dengan institusi. Komunikasi yang persuasif adalah fokus utama dalam cause marketing, dengan tujuan menciptakan kesadaran dan perhatian kepada isu sosial dan atau untuk mengajak donor potensial dan sukarelawan untuk berkontribusi dalam sebuah cause atau berpartisipasi dalam aktivitas untuk mendukung cause. Sejak signifikannya angka penyebaran Covid-19 dan langkanya alat pelingdung diri (APD) bagi tenaga medis dan masyarakat umum, Universitas Abdurrab telah banyak melakukan kegiatan amal atau sosial yang melibatkan masyarakat umum. Dosen dan mahasiswa saling bergerak dan berusaha untuk dapat berkontribusi. Berikut adalah salah satu bentuk kegiatannya :

Gambar 4. Dukungan Universitas Abdurrab Untuk Program Sosial

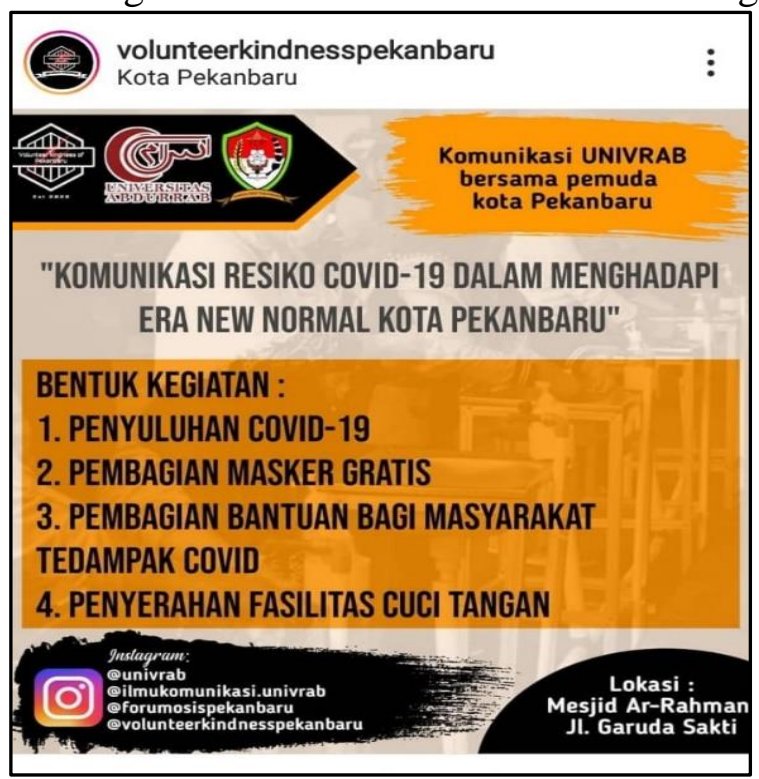

Sumber : Dokumentasi Universitas Abdurrab 
Ketiga, viral marketing, menciptakan pesan yang menghibur dan informatif yang didesain untuk disebarkan secara eksponensial melalui media elektronik. Pertumbuhan eksponensial dapat menyebabkan hasil yang mengejutkan, karena kecepatan perubahan yang dihasilkannya meningkat drastis seiring berjalannya waktu. Berikut adalah salah satu bentuk pesannya :

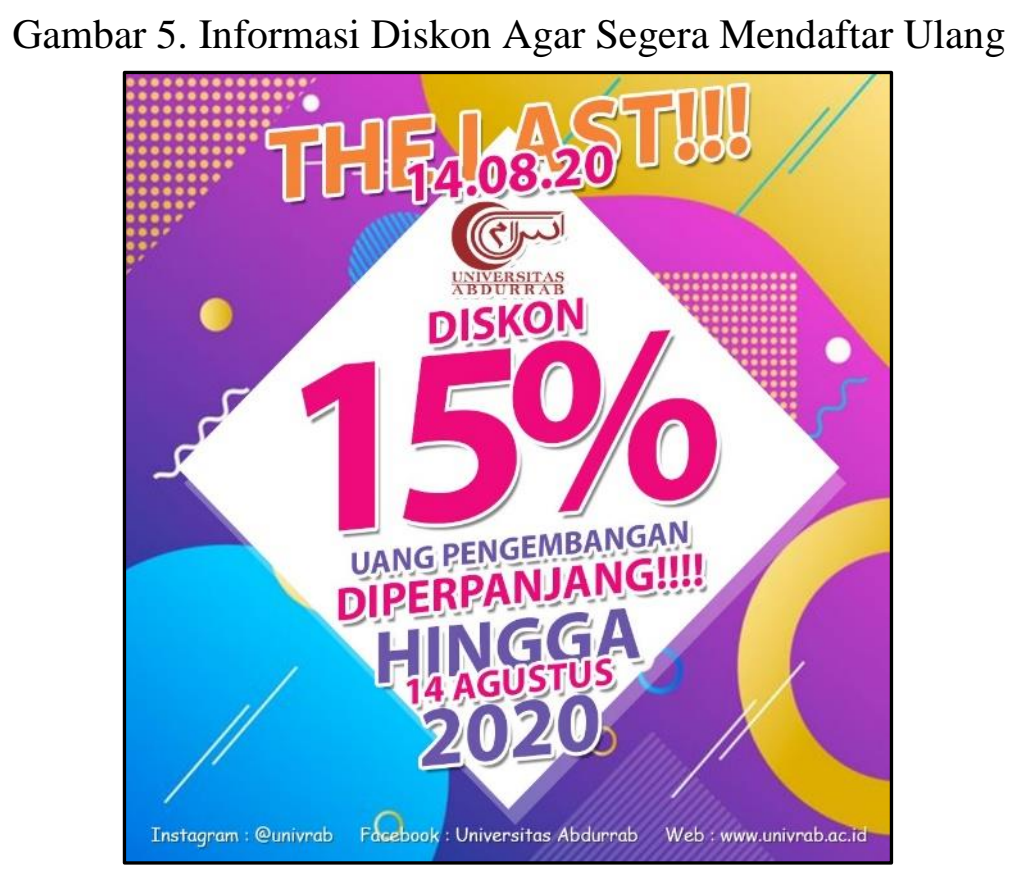

Sumber : Dokumentasi Universitas Abdurrab

Keempat, influencer marketing, mengidentifikasi komunitas kunci dan key opinion leader yang dengan senang hati menceritakan kualitas dan memiliki kemampuan untuk mempengaruhi opini orang lain. Influencer marketing merupakan salah satu strategi pemasaran di mana perusahaan mengajak seorang influencer bekerja sama untuk meningkatkan brand awareness dan penjualan sesuai dengan target pasar yang ditentukan.

Dalam hal ini Universitas Abdurrab menggunakan kekuatan dari influencer mikro Di mana influencer mikro biasanya memiliki jumlah follower 10 ribu orang, bahkan kurang. Namun, mereka memiliki keterikatan (engagement) dengan followernya. Influencer mikro juga memiliki audiens yang lebih spesifik pada niche (topik) tertentu. Dengan memahami audiensnya, seorang influencer mikro mampu membuat konten yang lebih relevan dengan followernya. Dan berikut adalah kegiatan Universitas Abdurrab yang dilakukan dengan melibatkan influencer atau key opinion leader (KOL) seperti komunitas ketua Osis. Ketua Osis adalah orang-orang yang memiliki kekuatan untuk memengaruhi sebuah keputusan siswa-siswi lainnya di sekolahnya masing-masing, pada umumnya akan lebih didengar oleh khalayak umum, karena mereka dianggap orang yang memiliki pengetahuan dan pengalaman lebih.

Berkaitan dengan KOL, biasanya juga digunakan perusahaan untuk melakukan review atau memberikan testimoni terhadap produk yang dijual melalui social media, khususnya Instagram. KOL adalah salah satu aset penting bagi perusahaan, jika memilih KOL yang tepat, strategi word of mouth akan berjalan dengan baik. 
Gambar 6. Universitas Abdurrab Berkolaborasi Dengan Forum OSIS Pekanbaru

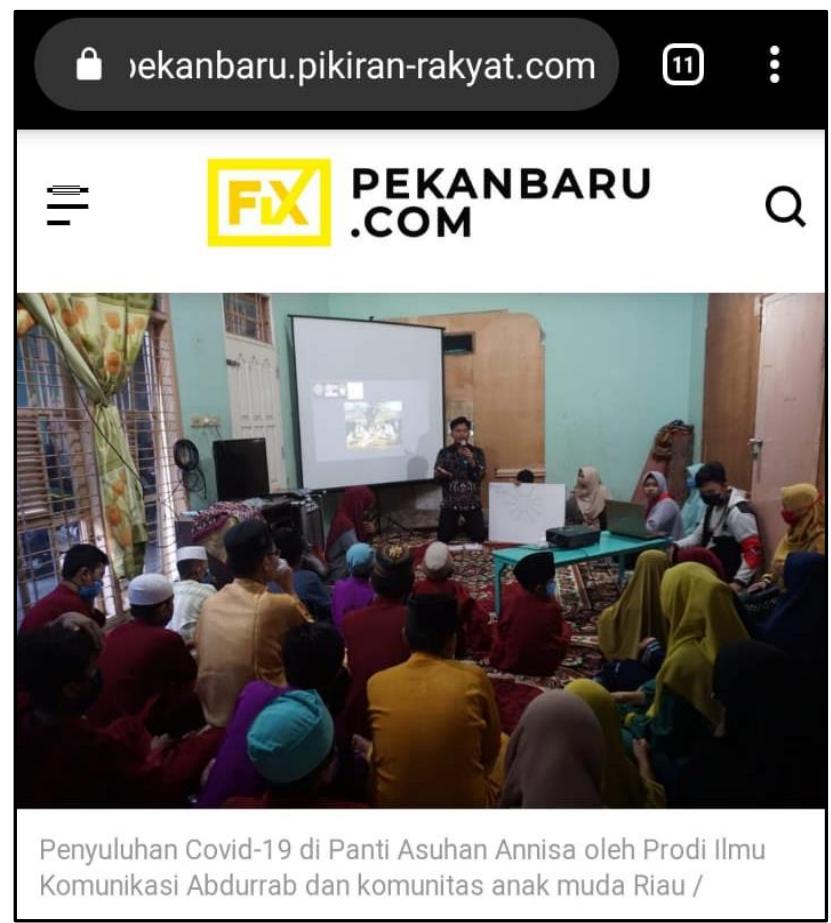

Sumber : Dokumentasi Universitas Abdurrab

Berdasarkan pemaparan di atas, WOM adalah strategi pemasaran yang lebih simpel dan tidak membutuhkan biaya yang besar, namun memiliki tingkat efektif yang cukup besar. Di masa Covid-19 yang tantangannya jauh lebih besar. Universitas Abdurrab menunjukkan grafik stabil cenderung naik jumlah mahasiswa barunya, seperti terlihat pada gambar berikut :

Gambar 7. Grafik Komparasi Perkembangan PMB 2020

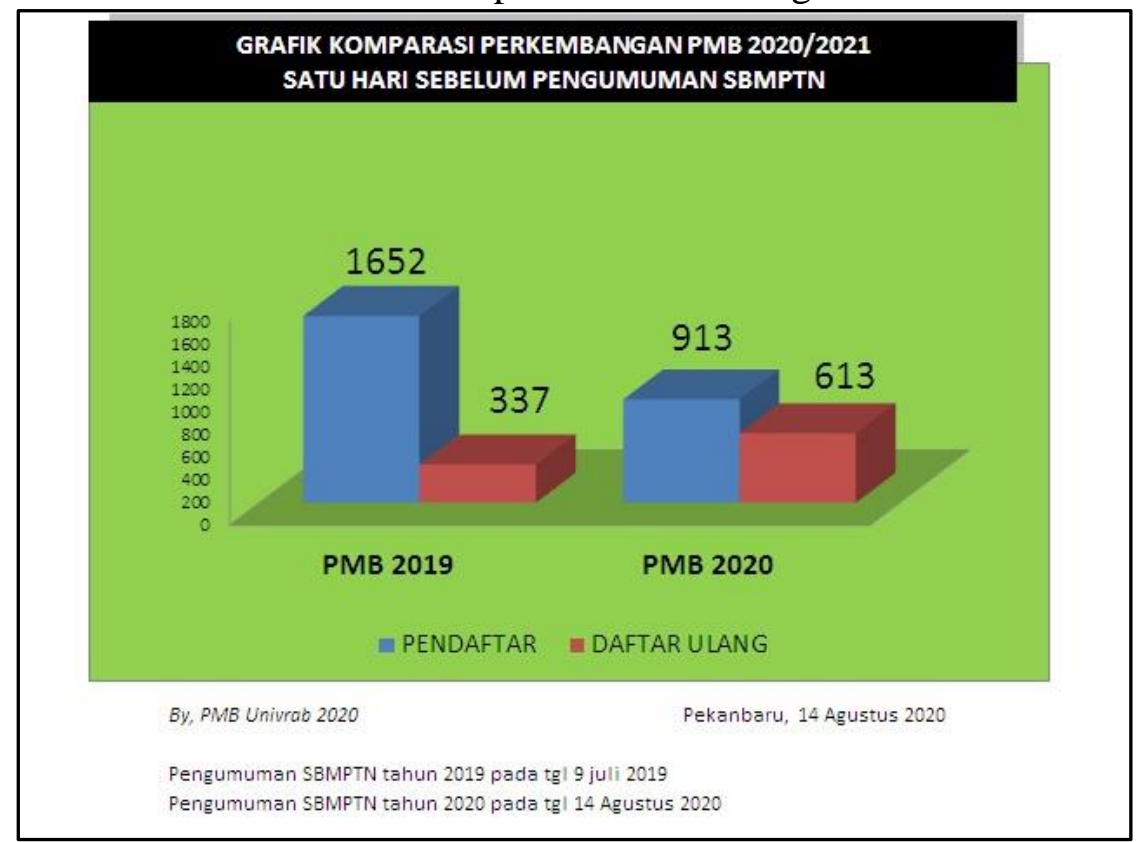

Sumber : Dokumentasi Universitas Abdurrab 
Dari gambar 7 diketahui bahwa satu hari menjelang pengumuman SBMPTN 2020 Universitas Abdurrab telah menerima 913 Mahasiswa baru dengan 613 orang di antaranya sudah melakukan daftar ulang. Artinya terjadi dua kali lipat lonjakan pendaftar yang sudah mendaftar ulang dan kemungkinan berkuliah di Universitas Abdurrab semakin besar.

Strategi ini dianggap sangat cocok diterapkan, karena kebanyakan orang Indonesia senang bersosialisasi dan berkumpul dengan teman-temannya. Banyak dari mereka juga memiliki kebiasaan untuk menanyakan ke teman terdekatnya tentang suatu universitas sebelum mendaftar. Jika temannya bilang kampus A lebih baik, mereka akan dengan mudahnya percaya. Inilah yang membuat strategi Word of Mouth masih berjalan hingga sekarang.

\section{Simpulan}

Positive Word of Mouth memiliki kekuatan tersendiri untuk menjadi strategi yang dapat diandalkan dalam proses persuasi calon mahasiswa baru untuk bersedia kuliah di Universitas Abdurrab. Aktivitas WOM yang dimaksud merupakan komunikasi di antara mahasiswa atau masyarakat luas tentang kualitas institusi di mana tidak ada tujuan spesifik dari komunikasi yang dilakukan. Positive WoM mengacu pada rekomendasi yang baik dari seseorang kepada orang lain tentang produk, jasa atau merek perusahaan. Dalam persaingan yang semakin ketat, usaha untuk memberikan service quality yang superior dan menciptakan student satisfaction yang tinggi dirasakan sangat penting bagi Universitas Abdurrab, karena student satisfaction yang tinggi pada akhirnya akan berdampak terhadap WOM. Apabila mahasiswa puas terhadap kualitas pelayanan yang diberikan, maka akan menimbulkan peningkatan kesetiaan, sehingga meningkatkan niat mahasiwa untuk merekomendasikan pelayanan institusi pada orang-orang terdekat. Terdapat beberapa metode yang dipakai Universitas Abdurrab untuk menciptakan atau merangsang terjadinya positive word of mouth sebagai alat komunikasi pemasaran saat pandemi Covid-19 yakni buzz marketing, cause marketing, viral marketing dan influencer marketing.

\section{Referensi}

Fadillah, D. (2015). Model Komunikasi "WOM" Sebagai Strategi Pemasaran Efektif. Humanika, Kajian Ilmiah Mata Kuliah Umum, 15(1), 66-74.

Putri, Y. R. (2018). Strategi Pemasaran Dengan Menggunakan Word of Mouth Marketing Pada Produk Simpanan (Si Bagus) Dalam Meningkatkan Jumlah Anggota di Koperasi Simpan Pinjam Giri Muria Group Kudus. Tugas Akhir, UIN Walisongo Semarang.

Riorini, S. V., \& Widayati, C. C. (2018). Bagaimana Meningkatkan Positive Word Of Mouth Mahasiswa Perguruan Tinggi Swasta. In Prosiding Seminar Nasional Pakar (pp. 27-33).

Sernovitz, A. (2006). Word of mouth marketing: How Smart Companies Get People Talking. Chicago: Kaplan Publishing

Setyawan, S. (2015). Strategi Pemasaran Perguruan Tinggi Swasta. Akutansi Bisnis \& Manajemen (ABM), 22(1), 9-18.

Sopandi, E. (2011). Strategi Promosi Penerimaan Mahasiswa Baru Untuk Pts (Tinjauan Atas Kegiatan Promosi PTS di Jawa Barat Tahun 2010). Manajerial: Jurnal Manajemen dan Sistem Informasi, 10(1), 87-101.

Suryani, T., Mulyati, A., \& Maduwinarti, A. (2017). Pengaruh Word Of Mouth Terhadap Keputusan Pembelian Laptop LENOVO di Kalangan Mahasiswa Surabaya di Kota Surabaya. Jurnal Dinamika Administrasi Bisnis, 3(2). 